\title{
PENGARUH KIPAS TERHADAP WAKTU DAN LAJU PENGERINGAN MESIN PENGERING PAKAIAN
}

\author{
P.K. Purwadi ${ }^{1}$, Wibowo Kusbandono ${ }^{2}$ \\ Jurusan Teknik Mesin Fakultas Sains dan Teknologi, \\ Universitas Sanata Dharma ${ }^{(1,2)}$,Yogyakarta. \\ Email : pkpurwadi1966@gmail.com ${ }^{1}$
}

\begin{abstract}
The purpose of this research, in addition to design and assemble clothes dryers, as well as to determine the influence of the fan in the space of clothes dryers with respect to the time required for drying clothes and the rate of drying clothes, with initial conditions wet clothes different i.e the results of squeeze of hand and the results of squeeze of washing machine. Research carried out on the clothes dryer that works with electric energy sources and using the vapor compression cycle. Total electric power required is $2,588 \mathrm{~kW}$. The clothes dryer works to get dry air at a high enough temperature that can be used for drying clothes. The clothes dryer works with open systems, meaning that the air which has been used for drying clothes immediately dumped out of the clothes dryer. The working fluid used in drying clothes is the outdoor air, whereas the working fluid that is used for the vapor compression cycle is R134a. The research was conducted by using 50 batik clothes from Pekalongan, size XL, which has a total dry weight of 7660 grams. Research results: (a) the clothes dryer can work well without a jam occurs during machine work, when no load, the air condition in the space of clothes dryers has a dry bulb temperature $72^{\circ} \mathrm{C}$ and wet bulb temperature $29.3^{\circ} \mathrm{C}(\mathrm{b})$ for the initial conditions of the wet clothes outcome of squeeze of hand, the presence of the fan working in the space of clothes dryers is able to shorten the drying time of the clothes about $40 \%$ and can increase the rate of drying clothes about $67 \%$ (b) for the initial conditions of the wet clothes outcome of squeeze of washing machine, the presence of fan working in the space of clothes dryers is able to shorten the drying time of clothes approximately $39 \%$ and can increase the drying rate of about $65 \%$.
\end{abstract}

Keywords : Clothes Dryers, Vapor Compression Cycle, R134a, Open System.

\section{PENDAHULUAN}

Hal yang penting untuk diketahui dari mesin pengering pakaian, selain kapasitas maksimum pakaian yang dapat dikeringkan, juga waktu yang diperlukan untuk melakukan proses pengeringan pakaian serta laju pengeringan pakaian. Dengan demikian pengguna dapat memilih mesin pengering pakaian yang sesuai dengan keinginannya. Apakah untuk keperluan rumah tangga ataukah untuk keperluan usaha. Bila untuk keperluan usaha (misalnya untuk jasa laundry), dapat memilih mesin dengan kapasitas pengeringan pakaian yang cukup besar dan dengan dengan waktu pengeringan pakaian yang relatip singkat.

Beberapa hal yang dapat mempercepat proses pengeringan pakaian adalah (a) kondisi udara yang dipergunakan di dalam proses pengeringan, meliputi suhu dan kelembaban (b) bahan pakaian yang dikeringkan (c) kondisi awal pakaian sebelum dikeringkan (d) kecepatan aliran udara yang dipergunakan di dalam pengeringan pakaian, dan lain sebagainya. Pada penelitian ini, penelitian difokuskan untuk melihat seberapa besar pengaruh kecepatan aliran udara yang dipergunakan di dalam proses pengeringan pakaian.

Bagi pengusaha laundry, waktu pengeringan sangat penting untuk diketahui, supaya target pengeringan pakaian yang diinginkan perharinya dapat dipenuhi. Dengan demikian usahanya akan dapat berjalan lancar dan tidak akan menimbulkan masalah dengan para pelangannya. Terutama pada waktu musim hujan tiba. Bila usaha laundry berjalan lancar dan meningkat dari waktu ke waktu, maka kebutuhan mesin pengering yang memiliki kapasitas pakaian yang besar dan waktu pengeringan yang cepat pakaian sangat diperlukan. 
Keuntungan penggunaan mesin pengering pakaian dengan energi listrik yang memakai siklus kompresi - uap ada beberapa hal, seperti : (a) praktis, atau mudah menghidupkan dan mematikan mesin (b) ramah lingkungan, atau tidak menimbulkan masalah atau polusi dengan lingkungannya (c) aman, karena kecil kemungkinan menimbulkan bahaya, sehingga saat mesin beroperasi, dapat ditinggal (d) tidak cepat merusak pakaian, karena suhu udara yang dipergunakan untuk proses pengeringan pakaian relatip tidak tinggi, dan (e) dapat dipergunakan kapan saja : malam hari atau saat hari hujan. Sedangkan kerugiannya, memerlukan konsumsi energi listrik yang cukup besar. Jika dipakai untuk usaha, biaya listrik dapat dibebankan kepada pelanggan.

Perancangan mesin pengering pakaian dengan mempergunakan energi listrik telah dilakukan beberapa orang, seperti Goldberg (2005), Maruca (2008), Bison dan Alberto (2012), Beers (2013), serta Balioglu (2013). Energi listrik yang dipergunakan di dalam perancangan mesin tersebut, untuk menggerakkan komponen utama kompresor yang bekerja bersama - sama dengan komponen lain didalam siklus kompresi uap, dan menggerakkan beberapa kipas yang dipergunakan untuk mengalirkan sirkulasi udara yang akan melewati pakaian - pakaian yang akan dikeringkan di dalam ruang pengering pakaian.

Berangkat dari persoalan tersebut, penulis tertarik untuk merancang, merakit dan melakukan penelitian terkait mesin pengering pakaian, yang memiliki kapasitas pengeringan pakaian yang cukup besar (maksimal 50 pakaian dewasa) dengan waktu pengeringan yang relatip cepat. Di rancang untuk keperluan usaha, seperti jasa laundry. Seberapa besarkah pengaruh adanya kipas di dalam ruang pengering pakaian terhadap waktu yang diperlukan untuk mengeringkan pakaian?

\section{DASAR TEORI}

\subsection{Siklus Kompresi Uap}

Skematik rangkaian komponen utama siklus kompresi uap, disajikan pada gambar 1. Siklus kompresi uap pada diagaram $p-h$ disajikan pada gambar 2. Komponen utama dari mesin kompresi uap meliputi: kompresor, evaporator, kondensor dan pipa kapiler. Komponen tambahan lain yang dipergunakan dalam siklus kompresi uap adalah : filter dan kipas lengkap dengan motor penggeraknya. Fluida kerja pada siklus kompresi uap dinamakan dengan refrigeran, dan pada penelitian ini dipilih R134a, yang ramah lingkungan. Filter ditempatkan sebelum pipa kapiler, berfungsi untuk menyaring kotoran - kotoran yang ada pada refrigeran, agar fluida kerja sebelum masuk pipa kapiler dalam keadaan yang benar benar bersih dari kotoran. Adanya filter, memperkecil kemungkinan pipa kapiler mengalami kebuntuan.

Siklus kompresi uap meliputi 4 proses utama : (a) proses penaikkan tekanan (berlangsung dikompresor, secara isentropis), (b) proses pembuangan kalor (berlangsung pada tekanan tetap), meliputi: proses - proses: desuperheating, kondensasi, dan pendinginan - lanjut (berlangsung ini setelah refrigeran keluar dari kompresor sampai sebelum masuk pipa kapiler, dengan melalui kondensor), proses penurunan tekanan (berlangsung di pipa kapiler, berlangsung pada nilai enthalpi yang tetap), dan proses evaporasi dengan pemanasan lanjut (proses berlangsung pada tekanan tetap di evaporator sampai sebelum masuk kompresor).

Pada siklus kompresi uap, evaporator berfungsi untuk menyerap kalor dari lingkungannya. Kalor yang diserap oleh evaporator $\left(Q_{\text {in }}\right)$ diambil dari udara yang dipergunakan untuk proses pengeringan pakaian ketika udara dilewatkan evaporator. 
Ketika udara dilewatkan evaporator, udara mengalami proses pendinginan dan proses pengembunan, sehingga udara mengalami proses penurunan kelembaban spesifik. Di dalam siklus kompresi uap, kalor yang diambil evaporator dipergunakan untuk mengubah wujud refrigeran dari wujud campuran cair dan gas menjadi gas seluruhnya bahkan dapat mencapai kondisi gas panas lanjut. Kondensor didalam siklus kompresi uap berfungsi untuk melepas kalor ke udara yang melewatinya. Udara yang dilewatkan kondensor ini, merupakan udara yang dipergunakan untuk proses pengeringan pakaian. Didalam mesin pengering pakaian ini, udara pengering pakaian dapat melewati kondensor dan evaporator karena adanya kipas yang diletakkan didekat kondensor. Kondisi udara setelah melewati kondensor mengalami kenaikan suhu udara bola kering dan suhu udara bola basah, sehingga kemampuan udara dalam menyerap uap air semakin besar. Kelembaban udara relatif mengalami penurunan.

Pada siklus kompresi uap, evaporator berfungsi untuk menyerap kalor dari lingkungannya. Kalor yang diserap oleh evaporator $\left(Q_{\text {in }}\right)$ diambil dari udara yang dipergunakan untuk proses pengeringan pakaian, ketika udara dilewatkan evaporator. Ketika udara dilewatkan evaporator, udara mengalami proses pendinginan dan proses pengembunan, sehingga udara mengalami proses penurunan kelembaban spesifik. Di dalam siklus kompresi uap, kalor yang diambil evaporator dipergunakan untuk

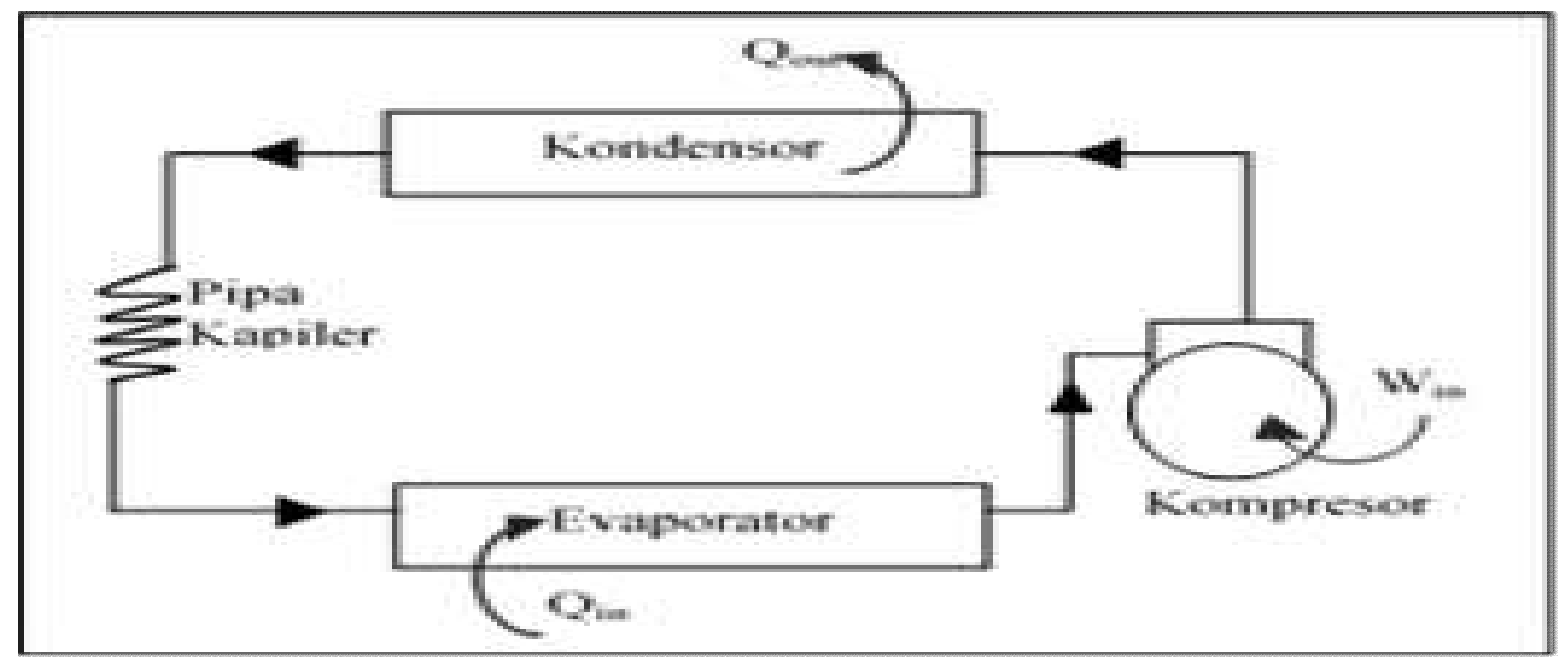

Gambar 1. Rangkaian Komponen Siklus Kompresi Uap.

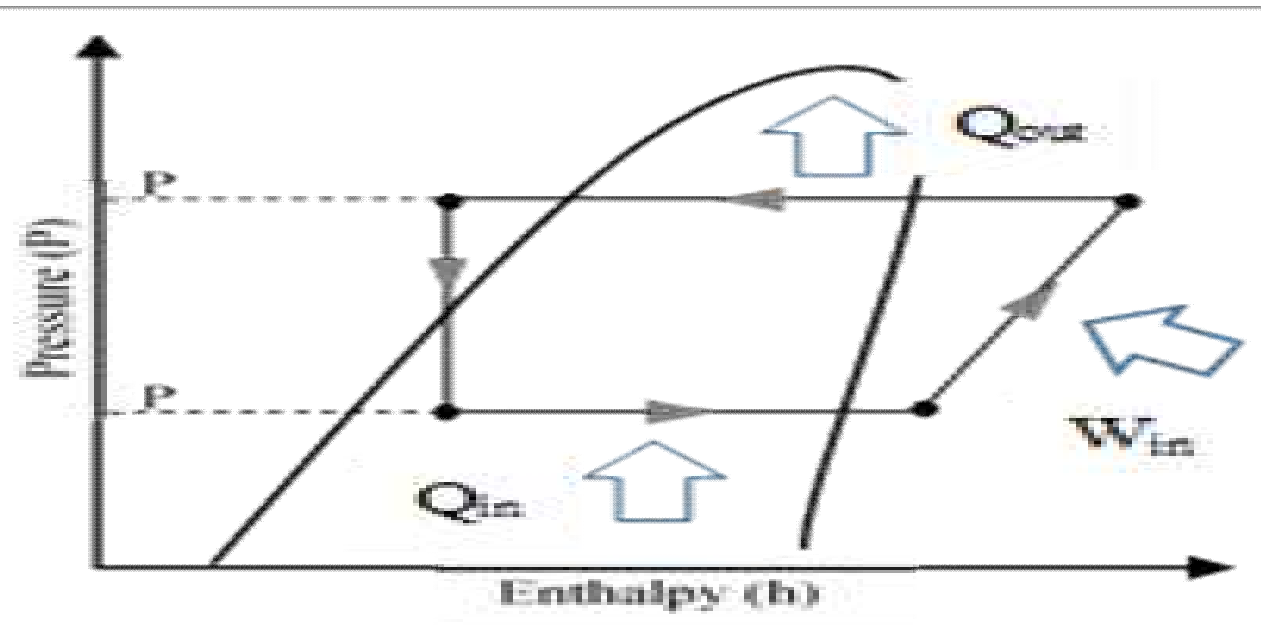

Gambar 2. Siklus Kompresi Uap Pada P-H Diagram. 
mengubah wujud refrigeran dari wujud campuran cair dan gas menjadi gas seluruhnya bahkan dapat mencapai kondisi gas panas lanjut. Kondensor didalam siklus kompresi uap berfungsi untuk melepas kalor ke udara yang melewatinya. Udara yang dilewatkan kondensor ini, merupakan udara yang dipergunakan untuk proses pengeringan pakaian. Didalam ruang mesin pengering pakaian ini, udara pengering pakaian dapat melewati kondensor dan evaporator karena adanya kipas yang diletakkan di dekat kondensor. Kondisi udara setelah melewati kondensor mengalami kenaikan suhu udara bola kering dan suhu udara bola basah, sehingga kemampuan udara dalam menyerap uap air semakin besar. Kelembaban udara relatif mengalami penurunan.

\subsection{Mesin Pengering Pakaian}

Gambar 3 menyajikan skematik dari rangkaian mesin pengering baju sistem terbuka yang di pergunakan di dalam penelitian. Fluida kerja yang dipergunakan untuk proses pengeringan pakaian adalah udara yang berasal dari udara luar. Udara luar masuk ke pengering pakaian melalui ruang mesin pengering udara (mesin siklus kompresi uap). Udara masuk melalui pintu masuk udara dari mesin pengering udara yang kemudian melewati evaporator dari komponen siklus kompresi uap. Udara keluar dari mesin pengering pakaian melalui pintu keluar dari ruang pengering pakaian, setelah udara dipergunakan untuk mengeringkan semua pakaian. (Lihat Gambar 3).

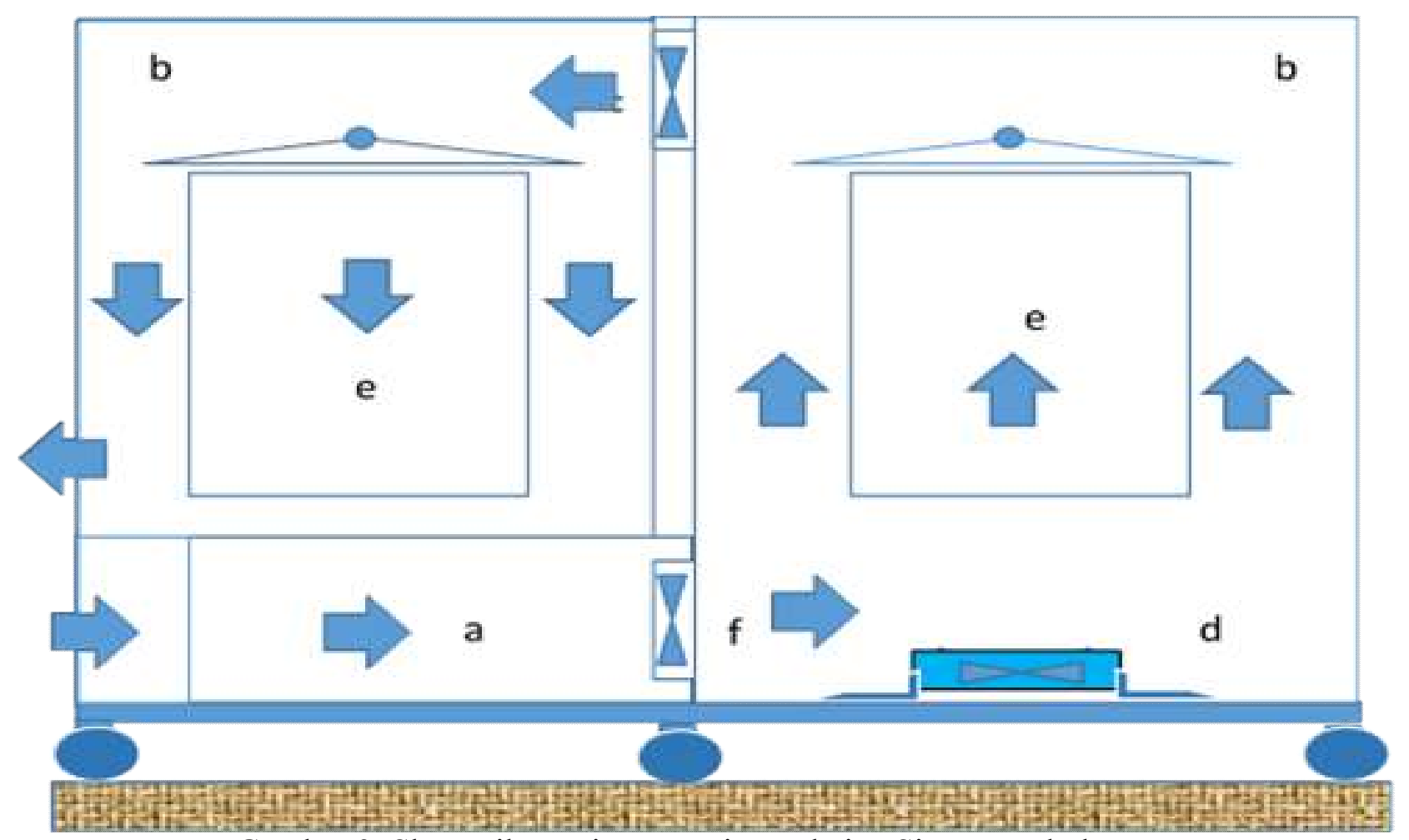

Gambar 3. Skematik Mesin Pengering Pakaian Sistem Terbuka.

\section{Keterangan :}

(a) Ruang Mesin Siklus Kompresi Uap.

(b) Ruang Pengering Pakaian.

(c) Kipas Angin yang Mengalirkan Udara dari Ruang Pengering ke Luar dari Ruang.

(d) Kipas di Dalam Lemari Pengering.

(e) Pakaian.

(f) Kipas Kondensor. 


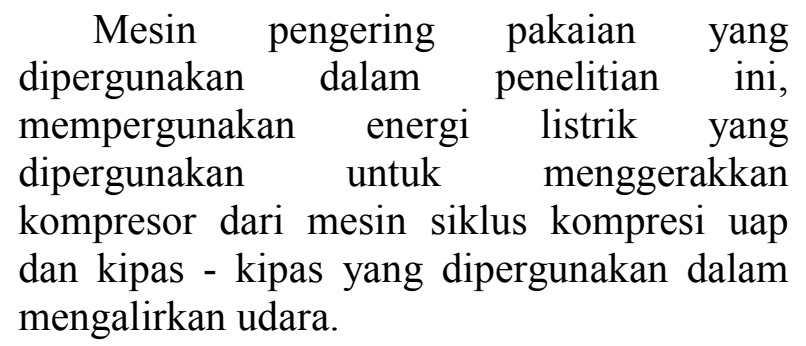

Udara yang dipergunakan dalam pengeringan pakaian berasal dari udara luar yang kemudian diolah oleh mesin siklus kompresi uap. Udara hasil olahan ini kemudian dialirkan ke ruang pengering pakaian untuk dipergunakan mengeringkan pakaian di dalam ruang pengering pakaian, yang dialirkan masuk ke dalam ruang pengering. Udara hasil pengolahan, mempunyai kondisi udara kering dengan suhu udara yang cukup tinggi. Udara menjadi kering karena adanya evaporator didalam mesin siklus kompresi uap yang mengambil massa uap air didalam udara, dan udara menjadi bersuhu cukup tinggi karena adanya kompresor dan kondensor didalam mesin siklus kompresi uap yang keduanya memberikan energi - kalor ke udara. Sistem terbuka yang dipergunakan di dalam mesin pengering ini berarti udara yang di sirkulasikan didalam ruang pengering, setelah dipergunakan untuk mengeringkan pakaian, dibuang keluar dari sistem pengeringan pakaian. Udara yang dibuang memiliki nilai kandungan air yang tinggi. Saat udara masuk ruang pengering pakaian, udara dilewatkan melalui pakaian - pakaian yang digantung di hanger baju. Ketika udara melewati permukaan pakaian, udara kering akan mengambil air yang ada di dalam pakaian.

Sehingga pakaian menjadi lebih kering. Udara keluar dari ruang pengering memiliki nilai kelembaban relatif dan kelembaban spesifik yang lebih tinggi dibanding ketika udara memasuki ruang pengering, tetapi suhu udara bola kering menurun.

\section{METODE PENELITIAN}

Pengujian mesin pengering untuk mendapatkan data - data penelitian dilakukan di laboratorium. Mesin pengering penelitian merupakan hasil rakitan sendiri, dengan mempergunakan komponen - komponen standar dari siklus kompresi uap yang ada di pasaran.

\subsection{Obyek Penelitian}

Obyek dari penelitian ini adalah mesin pengering pakaian dengan gambar skematik seperti tersaji pada gambar 3. Tanda panah menunjukkan arah aliran udara, dari udara luar masuk sampai udara keluar dari mesin pengering pakaian. Jumlah mesin siklus kompresi uap ada dua. Daya kompresor di setiap mesin kompresi uap sekitar 1100 watt, berjenis rotari, komponen utama yang lain menyesuaikan dengan besarnya daya kompresor. Perhitungan daya kompresor didasarkan pada hasil perkalian antara arus listrik yang dipergunakan ketika kompresor bekerja (sekitar 5 ampere) dengan tegangan listrik yang dipergunakan sekitar $220 \mathrm{~V}$. Besarnya daya yang dihasilkan ini berbeda dengan yang tertera di name plate nya dengan besar 1 pk. Hal ini disebabkan karena suhu kerja evaporator sengaja diturunkan dari suhu kerja normal, dan suhu kerja kondensor sengaja ditingkatkan dari suhu kerja kondensor normal. Evaporator dan kondensor yang dipergunakan berjenis pipa u bersirip, dengan pipa dari bahan tembaga dan sirip dari bahan alumunium, pipa kapiler terbuat dari bahan tembaga dengan diameter pipa 0,032 inci. Kipas untuk mengalirkan udara melewati kondensor disetiap mesin siklus kompresi uap memiliki daya 54 watt. Sedangkan kipas yang dipergunakan untuk mengalirkan udara dari ruang pengering pakaian depan ke ruang pengering pakaian belakang ada dua, masing - masing memiliki daya 50 watt. 
Kipas ini sekaligus mendorong udara keluar dari mesin pengering pakaian. Kipas yang ada di ruang pengering pakaian depan ada 2 , masing masing memiliki daya 90 watt. Ukuran pengering pakaian : $\mathrm{p}$ x 1 x t : 1,5 $\mathrm{m} \mathrm{x}$ $1,2 \mathrm{~m} \mathrm{x} 1,6 \mathrm{~m}$. Jumlah pakaian yang dikeringkan sekaligus di dalam penelitian ini, sebanyak 50 pakaian untuk sekali proses pengeringan. Jenis pakaian batik dari Pekalongan, ditentukan dengan ukuran XL.

\subsection{Variasi Penelitian}

Variasi penelitian yang dilakukan adalah kondisi kipas yang berada di dalam ruang pengeringan pakaian bagian depan: (a) kondisi kipas tidak bekerja (atau off) dan (b) kondisi kipas bekerja (on). Kondisi awal pakaian basah yang akan dikeringkan juga divariasikan : (a) kondisi pakaian basah hasil perasan tangan dan (b) kondisi pakaian basah hasil perasan mesin cuci. Hasil akhir yang ingin diperoleh adalah waktu pengeringan dan laju pengeringan pakaian yang diperlukan untuk mengeringkan 50 pakaian dari kondisi awal basah sampai pakaian dalam keadaan kering.

\subsection{Data Penelitian}

Data penelitian diambil langsung selama proses pengeringan pakaian, dimulai ketika mesin sudah dihidupkan dan diakhiri ketika mesin sudah dihentikan. Mesin dihentikan ketika pakaian yang dikeringkan sudah kering. Tingkat kekeringan pakaian akhir diambil sama dengan kondisi ketika pakaian awal kering sebelum pakaian dibasahi, atau berat pakaian kering akhir sudah samadengan berat awal pakaian sebelum pakaian dibasahi. Waktu yang diperlukan untuk pengeringan 50 pakaian secara serentak dicatat baik pada saat tanpa mempergunakan kipas maupun pada saat mempergunakan kipas.

\section{HASIL DAN DAN PEMBAHASAN}

Tabel 1 menyajikan data hasil penelitian dan gambar 4 menyajikan hasil penelitian dalam bentuk grafik. Data penelitian menyajikan proses pengeringan pakaian baik tanpa kipas bekerja maupun dengan kipas yang bekerja. Kondisi awal baju basah sebelum sebelum mengalami proses pengeringan di ruang pengering baju, dibedakan atas : (1) kondisi pakaian basah hasil perasan tangan dan (2) kondisi pakaian basah hasil perasan mesin cuci.

Ketika dilakukan penelitian, mesin pengering pakaian hasil rakitan dapat bekerja dengan lancar tanpa mengalami kemacetan, dan mampu mengeringkan pakaian dengan baik. Tidak mengalami overhead. Waktu pengeringan pakaian dengan mesin pengering energi listrik ini lebih cepat dibandingkan dengan pengeringan energi matahari. Untuk pakaian basah dengan kondisi awal diperas tangan, pengeringan dengan energi matahari memerlukan waktu sekitar 220 menit, sedangkan mesin pengering listrik hasil rakitan ini hanya sekitar 150 menit. Pada penelitian ini, kondisi udara masuk ruang pengering yang dihasilkan, memiliki suhu udara bola kering sekitar $72^{\circ} \mathrm{C}$, dan suhu udara basah sekitar $29,3^{\circ} \mathrm{C}$ (untuk kondisi tanpa kipas bekerja). Pada penelitian ini, berat awal 50 baju kering sebelum dibasahi dan dikeringkan sebesar 7660 gram (penimbangan pakaian kering dilakukan di luar lemari pengering).

Dari tabel 1, nampak bahwa hasil pengeringan 50 pakaian di dalam ruang ruang pengering, mampu menghasilkan berat yang lebih ringan (atau lebih rendah) dibandingkan dengan berat 50 pakaian kering awal sebelum dibasahi dan dikeringkan (7660 gram). 
Tabel 1. Data Pengeringan Pakaian

\begin{tabular}{|c|c|c|c|c|c|}
\hline \multirow{3}{*}{$\begin{array}{l}\text { Waktu } \\
\text { (menit) }\end{array}$} & \multicolumn{5}{|c|}{ Berat 50 Pakaian Selama Proses Pengeringan (gram) } \\
\hline & \multicolumn{2}{|c|}{$\begin{array}{c}\text { Kipas } \\
\text { di Lemari Pengering Tidak Bekerja }\end{array}$} & \multicolumn{2}{|c|}{$\begin{array}{c}\text { Kipas } \\
\text { di Lemari Pengering Bekerja }\end{array}$} & \multirow{2}{*}{$\begin{array}{c}\begin{array}{c}\text { Dengan } \\
\text { Energi } \\
\text { Matahari }\end{array} \\
\text { Diperas } \\
\text { Tangan }\end{array}$} \\
\hline & Diperas Tangan & $\begin{array}{c}\text { Diperas Mesin } \\
\text { Cuci }\end{array}$ & Diperas Tangan & $\begin{array}{c}\text { Diperas Mesin } \\
\text { Cuci }\end{array}$ & \\
\hline 0 & 17855 & 10855 & 17855 & 10855 & 17855 \\
\hline 20 & 15400 & 9350 & 14200 & 8750 & 15798 \\
\hline 35 & - & 8450 & - & - & - \\
\hline 40 & 13400 & 7750 & 11300 & & 14175 \\
\hline 42.5 & & & & 7656 & \\
\hline 60 & 11750 & 7654 & 9245 & & 13014 \\
\hline 70 & - & 9350 & - & & \\
\hline 80 & 10220 & & 7900 & & 12315 \\
\hline 90 & - & & 7656 & & \\
\hline 100 & 9100 & & & & 11390 \\
\hline 120 & 8300 & & & & 10251 \\
\hline 140 & 7720 & & & & 9498 \\
\hline 150 & 7657 & & & & \\
\hline 180 & - & & & & 8176 \\
\hline 220 & - & & & & 7660 \\
\hline
\end{tabular}

Hal ini di sebabkan, karena kondisi udara diluar lemari pengering berbeda dengan kondisi udara didalam lemari pengering. Kondisi udara didalam lemari pengering memiliki kelembaban relatif dan kelembaban spesifik yang lebih kecil di bandingkan dengan kelembaban relatif dan kelembaban spesifik diluar lemari pengering. Semakin rendah kelembaban spesifik yang dimiliki udara, maka kemampuan untuk mengeringkan pakaian semakin tinggi.

Dari data hasil penelitian dapat dinyatakan bahwa adanya kipas yang bekerja diruang pengering pakaian berpengaruh terhadap lama waktu yang diperlukan untuk pengeringan pakaian dan berpengaruh terhadap laju pengeringan pakaian. Dengan adanya kipas yang bekerja, udara di dalam ruang pengering menjadi lebih cepat mengalir dan bersirkulasi. Dengan kondisi itu, air yang melekat pada pakaian lebih cepat terambil oleh sirkulasi udara dan pakaian menjadi lebih cepat kering.
Waktu yang diperlukan untuk mengeringkan 50 pakaian secara serentak dengan tanpa kipas yang bekerja, dengan kondisi awal pakaian basah hasil perasan tangan, sekitar 150 menit, sedangkan dengan mempergunakan kipas yang bekerja, sekitar 90 menit. Hal ini berarti waktu pengeringan menjadi lebih pendek sekitar 60 menit. Terjadi pemendekan waktu pengeringan sekitar 40\%. Untuk hasil perasan mesin cuci, prosentase pemendekan waktu sekitar 39\%. Laju pengeringan pakaian juga mengalami perubahan, adanya kipas membuat laju pengeringan meningkat dari 0,33 pakaian per menit menjadi 0,55 pakaian per menit. Bila dinyatakan dengan prosentase, adanya penambahan kipas yang bekerja menyebabkan laju pengeringan meningkat sebesar $67 \%$ untuk kondisi awal baju basah hasil perasan tangan dan $65 \%$ untuk perasan mesin cuci (lihat Tabel 2 dan Tabel 3). 
Tabel 2. Waktu Pengeringan Pakaian

\begin{tabular}{c|c|c|c|c|c}
\hline \multirow{2}{*}{ No } & \multirow{2}{*}{ Kondisi Awal } & $\begin{array}{c}\text { Kaktu Pengeringan 50 Pakaian (menit) } \\
\text { Kipas di } \\
\text { Lemari } \\
\text { Pengering Tidak } \\
\text { Bekerja }\end{array}$ & $\begin{array}{c}\text { Kipas di Lemari } \\
\text { Pengering } \\
\text { Bekerja }\end{array}$ & $\begin{array}{c}\text { Penurunan Waktu } \\
\text { Pengeringan }\end{array}$ & $\begin{array}{c}\text { Prosentase } \\
\text { Penurunan }\end{array}$ \\
\hline 1 & Perasan Tangan & 150 & 90 & 60 & $40 \%$ \\
\hline 2 & $\begin{array}{c}\text { Perasan Mesin } \\
\text { Cuci }\end{array}$ & 70 & 42,5 & 27,5 & $39 \%$ \\
\hline
\end{tabular}

Tabel 3. Laju Pengeringan Pakaian

\begin{tabular}{l|c|c|c|c|c}
\hline \multirow{2}{*}{ No } & \multirow{3}{*}{ Kondisi Awal } & $\begin{array}{c}\mid c \\
\text { Kipas di } \\
\text { Lemari } \\
\text { Pengering Tidak } \\
\text { Bekerja }\end{array}$ & $\begin{array}{c}\text { Kipas di Lemari } \\
\text { Pengering } \\
\text { Bekerja }\end{array}$ & $\begin{array}{c}\text { Penurunan Waktu } \\
\text { Pengeringan }\end{array}$ & $\begin{array}{c}\text { Prosentase } \\
\text { Penurunan }\end{array}$ \\
\cline { 3 - 6 } 1 & Perasan Tangan & 0,33 & 0,55 & 0,22 & $67 \%$ \\
\hline 2 & $\begin{array}{c}\text { Perasan Mesin } \\
\text { Cuci }\end{array}$ & 0.71 & 1.18 & 0.46 & $65 \%$ \\
\hline
\end{tabular}

Waktu yang diperlukan untuk mengeringkan baju bergantung dari kondisi awal baju sebelum dikeringkan. Semakin sedikit air yang melekat di dalam baju, semakin cepat waktu yang diperlukan untuk pengeringan baju. Dari tabel 1 maupun tabel 2, dapat diketahui lamanya waktu pengeringan pakaian jika kondisi awal pakaian basah diperas dengan tangan dan dengan mesin cuci. Hasil perasan mesin cuci, mampu menghasilkan berat awal pakaian basah yang lebih ringan.
Kondisi ini menyebabkan, waktu yang diperlukan untuk mengeringkan pakaian lebih cepat. Pada saat ini, kecepatan putar pada drum dari mesin cuci yang dipergunakan untuk pengeringan awal pakaian (perasan mesin cuci) yang ada di pasaran memberikan variasi berbagai macam putaran. Dengan demikian pengguna dapat memilih berat awal pakaian basah yang ingin dikeringkan, sehingga waktu yang diperlukan untuk mengeringkan pakaian dapat diperkirakan. Semakin cepat drum berputar, semakin ringan berat awal pakaian basah yang akan dikeringkan. 


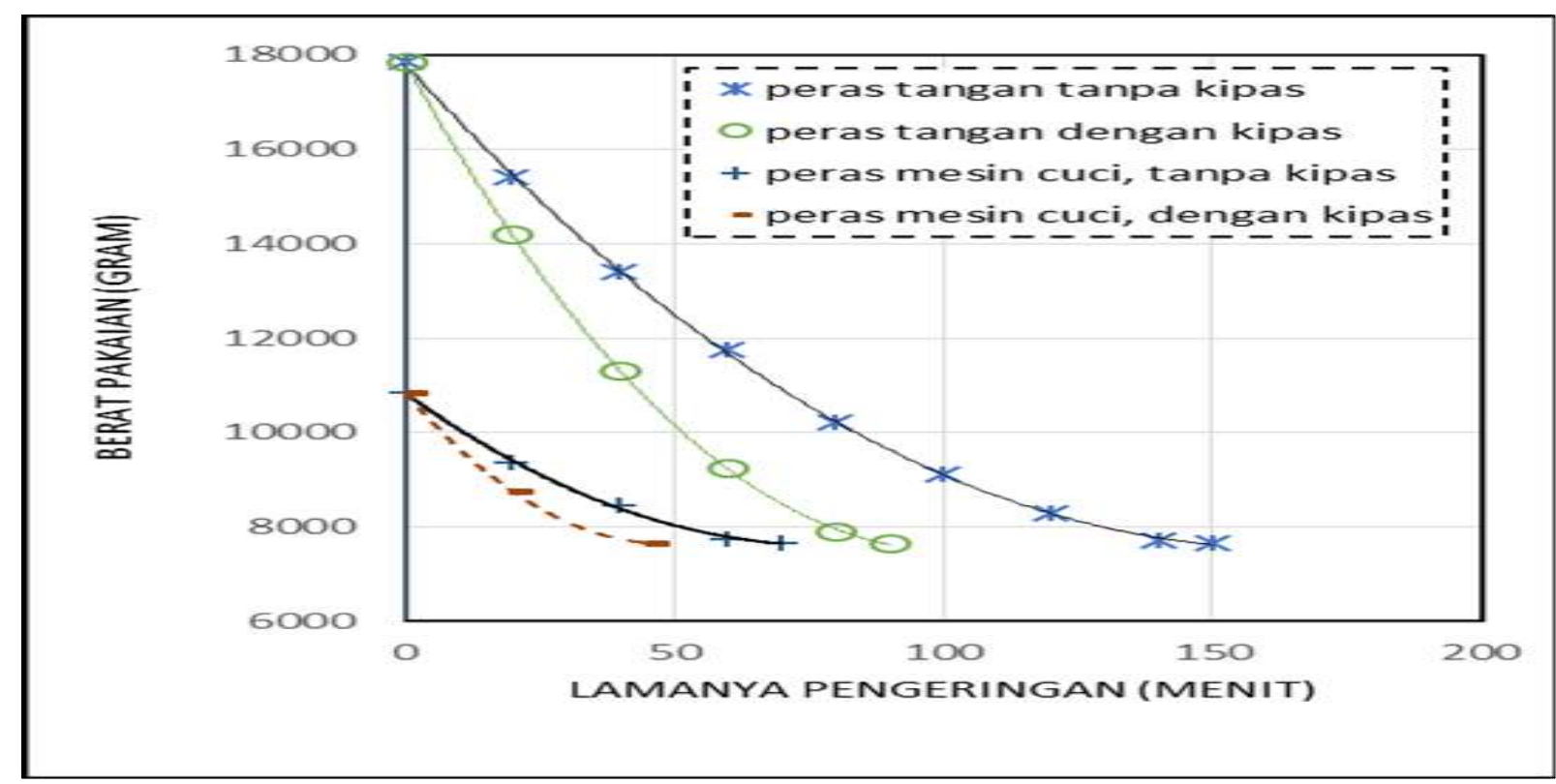

Gambar 4. Berat 50 Pakaian Selama Proses Pengeringan.

\section{KESIMPULAN}

Kesimpulan dari penelitian ini adalah :

a. Mesin pengering dapat bekerja dengan lancar dan tidak mengalami kemacetan selama mesin bekerja. Kondisi udara masuk ruang pengering yang dihasilkan (pada saat tanpa beban dan tanpa kipas bekerja) memiliki suhu udara bola kering sekitar $72^{\circ} \mathrm{C}$ dan suhu bola basah sekitar $29,3^{\circ} \mathrm{C}$.

b. Bila kondisi awal pakaian basah hasil perasan tangan, waktu yang diperlukan untuk mengeringkan 50 pakaian, tanpa kipas bekerja didalam lemari pengering, sekitar 150 menit dan bila dengan kipas bekerja sekitar 90 menit. Keberadaan kipas yang bekerja didalam ruang pengering, mampu memperpendek waktu pengeringan sekitar $40 \%$ dan mampu meningkatkan laju pengeringan pakaian sekitar $67 \%$. c. Bila kondisi awal pakaian basah hasil perasan mesin cuci, waktu yang diperlukan untuk mengeringkan 50 baju basah tanpa adanya kipas yang bekerja di dalam lemari pengering, sekitar 70 menit dan bila dengan kipas bekerja sekitar 42,5 menit. Keberadaan kipas yang bekerja didalam ruang pengering, mampu memperpendek waktu pengeringan sebesar $39 \%$ dan mampu meningkatkan laju pengeringan pakaian sekitar $65 \%$.

\section{Ucapan Terima Kasih}

Penulis mengucapkan terimakasih kepada (a) Pendidikan Tinggi yang berkenan memberikan kesempatan dan kepercayaan kepada penulis untuk melakukan penelitian ini melalui Program Hibah Bersaing Tahun 2, 2016 (b) LPPM USD yang selalu mendampingi sehingga pelaksanaan penelitian ini dapat berjalan dengan lancar (c) Fakultas Sain dan Teknologi USD yang telah memberikan ijin untuk mengikuti dan mendukung terlaksananya penelitian ini. 


\section{DAFTAR PUSTAKA}

Balioglu, et al, Heat Pump Laundry Dryer Machine, Patent Aplication Publication, Pub. No: US 2013/0047456 A1, Apr, 2013.

Beers, et al, Apparatus and Method for Refrigeration Cycle Elevation by Modification of Cycle Start Condition, United States Patent, Patent No: US 8,533,975 B2, 2013.

Bison, et al, Heat Pump Laundry Dryer and a Method for Operating a Heat Pump Laundry Dryer, Patent Aplication Publication, Pub. No: US 2012/0210597 A1, 2012.

Goldberg, et al, Heat Pump Clothes Dryer, Patent Aplication Publication, Pub. No: US 2005/0066538 A1., 2005.

Maruca, Low Temperature Clothes Dryer, United States Patent, Patent No: US 7,377,052 B2, 2008. 